\title{
Contextual Inferencing Strategies and Changes in Reading Attitudes: the Case of Iranian EFL Undergraduates
}

\section{Контекстуальні стратегії умовиведення та зміни в поглядах на читання: на прикладі іранських випускників EFL}

\section{Танназ Садегжи магістр}

\author{
Tannaz Sadeghi \\ MA
}

\section{E-mail: tannazsadeghi65@yahoo.com orcid.org/0000-0002-5459-8840}

\author{
Amin Marzban \\ Ph.D. in Applied Linguistics, \\ Амін Марцбан \\ кандидат наук \\ Assistant Professor \\ (прикладна лінгвістика), доцент
E-mail: a marzban eng@yahoo.com orcid.org/0000-0002-4299-2533

Pardis Islamic Azad University,

Department of English,

Shiraz Branch, Shiraz, Iran

$\triangle$ Sadra city, $5 \mathrm{Km}$, Shiraz, Iran, 71987 - 74731
Ісламський університет Азад, кафедра англійської мови, філія Шираз, Іран

$\triangle 5$ км., м. Шираз, Іран, $71987-74731$

Original manuscript received February 11, 2019

Revised manuscript accepted September 15, 2019

\section{ABSTRACT}

Objective. The present study examined the impact of contextual inferencing on Iranian EFL learners' attitudes towards reading in English.

Methods and techniques of the research. To achieve such goals, $60 \mathrm{BA}$ undergraduate students at Islamic Azad University of Shiraz, majoring in English teaching and English 
translation studies within the age range of 19-23 participated in the study. They were divided into two groups of control and experimental randomly. The data were collected through an 'Attitude towards Reading' questionnaire and a revised version of Demet Kulac's (2011) interview in two phases before and after the instruction.

Results. The comparison of pre- and post-questionnaires showed that contextual inferencing strategies had a positive effect on learners' attitudes towards reading, and there was a negative relationship between unknown vocabulary encounters and learners' attitudes towards reading English texts. Finally, the analysis of the interview confirmed the effectiveness of strategy training in reading attitudes and showed some other factors which were enhanced by using contextual inferencing strategies.

Conclusions. The findings contribute to syllabus designers and teachers in reading comprehension and international tests preparation courses.

Key words: contextual inferencing, lexical inferencing, learning strategies, reading attitudes, reading strategies.

\section{Introduction}

Reading is the most demanding skill in learning English. According to F. May (2001), in order to have a full comprehension in reading, the learner requires «a variety of highly flexible process called comprehension strategies» (p. 119). In many societies, it is important that a person be able to read well so that $\mathrm{s} / \mathrm{he}$ can be successful in life, but this does not mean that reading leads to success, but it is necessary to be a skillful reader in order to become successful (Grabe, 2009). R. Oxford (1990) claimed that inferencing strategies include using some linguistic or nonlinguistic clues to guess the meaning of the unknown words. However, some researchers stated that context does not always provide enough information and it is possible that learners may make wrong inferences and the strategy of inferencing works well with learners who have the skill of problem-solving (Bensoussan \& Laufer, 1984; Hulstijn, 1992: 114). Many studies have been done in order to investigate the effect of the contextual inferencing strategies on reading comprehension and some studies have been done to investigate the different aspects of vocabulary and reading.

Over the past few decades, there were much emphasis on learners' attitudes, motivation, beliefs, in second language acquisition (Gardner \& MacIntyre, 1993; Wenden, 1998). Masgoret, Bernaus, and Gardner (2001) stated that attitude can influence learners' motivation to learn another 
language. According to T. Merisuo-Storm (2007) and R. Oxford (1990), negative attitudes can retard the process of learning a new language; however, positive attitudes and feelings makes language learning more enjoyable and even more effective. It is also defined by Smith (as cited in Yamashita, 2004: 33) as «a state of mind, accompanied by feelings and emotions that makes reading more or less probable». According to U. Schiefele, E. Schaffner, J. Möller, and A. Wigfield (2012), reading attitude depends on the experienced feelings and emotions towards reading task which can be either negative or positive. Learners attitudes towards reading has an effect on both their motivation and reading success since it affects the amount of time a learner spends on reading activity (Lazarus \& Callahan, 2000). Moreover, T. Kaniuka (2010) tried to find the relationship between reading strategies and learners' attitudes towards reading. He concluded that those learners who received reading instruction, got higher scores in their attitudes towards reading, and as a result, he concluded that it is better to help EFL learners to have positive attitudes towards reading by using effective instructions in reading.

Most teachers agree that it is important to be knowledgeable in vocabulary and they believe that learning a second language demands learning vocabularies. A great number of ideas have been raised in order to prove how important vocabulary knowledge is in language acquisition. N. Schmitt (2004) claimed that there is a high relationship between learning vocabulary and proficiency in different aspects of language. According to some studies performed by L. Verhoeven and C. Perfetti (2008), reading comprehension has a strong relationship with decoding of words and language skills like vocabulary knowledge. They also claimed that vocabulary knowledge is the most significant factor in reading comprehension. According to Schmitt (2004), one of the most important factors in ascertaining the difficulty of an English text is the number of unknown vocabularies.

\section{Research Questions}

1. Does explicit instruction through contextual inferencing affect Iranian EFL undergraduates' attitudes towards English reading?

2. Is there any relationship between Iranian EFL undergraduates' encounters with unknown vocabularies in English texts and their attitudes towards reading in English? 
3. What are the Iranian EFL undergraduates' viewpoints regarding the effectiveness of contextual inferencing strategies in EFL classrooms?

\section{Previous Studies}

Reading is the most demanding skill in learning English. As P. Ur (1996) stated, reading is not only about decoding written symbols, but it means 'reading and understanding'. According to F. May (2001), in order to have a full comprehension in reading, the learner requires «a variety of highly flexible process called comprehension strategies» (p. 119). In many societies, it is important that a person be able to read well so that $\mathrm{s}$ /he can be successful in life, but this does not mean that reading leads to success, but it is necessary to be a skillful reader in order to become successful (Grabe, 2009). De Vignemont and T. Singer (2006) believe that readers have to adopt the writers' viewpoints in order to get the information of the text and comprehend it logically, and also to understand the characters' emotions and feelings.

According to J. Coady (1997), a learner with a low knowledge of vocabulary will be discouraged to read English texts, and when reading tasks decreases, the vocabulary growth will decrease as well. In addition, T. Paribakht and M. Wesche (1999) stated «the higher the academic level, the greater the vocabulary mastery needed» (p. 196). According to N. Schmitt (2004), one of the most important factors in ascertaining the difficulty of an English text is the number of unknown vocabularies. The difficulty of a text depends on the number of new vocabularies the text includes (Kilian et al., 1995).

S. Carton (1971) introduced contextual inferencing strategies as using the written text and the context in order to guess the meaning of new vocabularies. J. Walters (2004) stated that learners can use other ways to get the meanings of new vocabularies besides using dictionary. They can guess the meaning from the context and the cues exists in the context or they can ignore the new word they encountered; however, ignoring the word limits the learning potential and is not considered as a good way to cope with new words (Fraser, 1999). According to Nassaji (2006), those learners who have a high vocabulary knowledge are more successful in inferencing strategies than those with lower knowledge as they can have more accessibility to their background knowledge, and they are able to build an accurate semantic representation when they encounter an unfamiliar vocabulary. 
J. Walters (2006a-b) performed a research with participation of 44 ESL students at San Diego State University with different nationalities and proficiency levels. The design of the research was pre- and posttest with the aim of investigating the effectiveness of teaching three approaches of using the context to guess the word meanings. The three methods of teaching were one general strategy in order to get the meaning of the unknown words, teaching learners how to recognize and understand the context clues to use, and finally practicing with cloze exercises. The participants of the study received six hours of training and then the researcher gave them the post-test. After analyzing the data, the researcher noticed that the participants in experimental group performed better on the post-test and got higher scores in comparison to the control group. The results of the study indicated that training these methods had a positive effect on learners' reading comprehension.

Another study done by X. Fuping (2006) to investigate the effect of strategy training on learners' reading comprehension. Seventy-six intermediate EFL students participated in the study and were assigned to two groups of experimental and control. The researcher used a learning strategy questionnaire before and after the treatment. A reading test was used as the pre-test, and at the end of the treatment, another reading test were conducted by the researcher as the post-test. The results of the study revealed a significant improvement in the participants' post-test which could be concluded that the lexical strategies had a positive effect on learners' reading comprehension

\section{Methodology}

\section{Participants and Setting}

Sixty Iranian BA undergraduates majoring in Teaching English as a Foreign Language (TEFL) and Translation Studies at the English Department of Shiraz Azad University were selected through stratified sampling technique. They were homogenized based on Oxford Placement Test. The selected students were randomly assigned to two groups of experimental and control. Both male and female students (12 males, 48 females) within the age range of 19-23 (mean of age: 21 ) were selected to participate in this study. 


\section{Instruments}

To collect the necessary data for this study two instruments were utilized. First, an 'Attitudes towards Reading in English' questionnaire was administered to the participants. This questionnaire was developed by Figen Tezdiker (2007) and modified by the researcher. It was composed of four parts: a) personal information about the learners (i.e. name, gender, field of studies, and level), b) 31 items for attitudes of the learners towards reading and for joy of reading, scored on five-point-likert scale (i.e. strongly agree $=1$, agree $=2$, undecided $=3$, disagree $=4$, strongly disagree $=5$ ), c) one general question about their attitudes towards reading in a foreign language, and d) seven items for attitudes of learners towards unknown vocabulary encounters which were added to the questionnaire by the researcher from 'Attitude towards Reading in English' questionnaire by Demet Kulac (2016). The questionnaire was scored on five-point-likert scale to analyze the attitudes of the learners towards reading English texts. F. Tezdiker (2007) has also validated the original version of the questionnaire. Since the questionnaire was modified by the researcher, the validity was confirmed through pilot study during this research. To do so, thirthy EFL students were selected randomly from the target population, and homogenized through Oxford Placement test. Twenty learners were selected after the Oxford Placement test, and were assigned to two groups of control and experimental randomly. To ensure that the questionnaire used in this study enjoyed reliability, the researcher used the Cronbach Alpha reliability and it was reported as 0.78. In Order to elicit participants' viewpoints regarding the effectiveness of contextual inferencing strategies, a revised version of Demet Kulac's interview (2016) was used. There were five main questions for the students to respond to, and the responses were recorded by the researcher while interviewing, and analyzed according to the analysis of the interview used in Demet Kulac's article (2016).

\section{Data Analysis Procedure}

In order to test the effect of explicit instructions in contextual inferencing strategies and unknown vocabulary encounters on Iranian undergraduates' attitudes towards reading, the data gathered through the questionnaire were analyzed by using the Statistical Package for Social Sciences (SPSS) to see whether strategy training had a significant 
effect on learners' attitudes towards reading in English. In order to figure out the effect of unknown vocabulary encounters, the correlation between the learner's attitudes towards unknown vocabulary encounters and towards reading attitudes in English was calculated using Pearson Correlation Coefficient. As for the interview, qualitative techniques such as eyeballing, coding, sorting, and pattern building were applied to the recorded and transcribed data of the interview according to the qualitative analysis of the interview used in Demet Kulac's research in (2011), and discussed at the end of the study.

\section{Results and Discussion}

\section{RQ. 1. Results of the First Research Question}

Paired samples statistics was obtained for learners' pre- and posttest of control and experimental groups and their attitudes in order to find out if explicit instruction through contextual inferencing strategies have any effect on Iranian EFL learners' attitudes towards reading English texts as shown in table 1. Thereafter, the paired sample t-test was implemented to analyze and compare the mean scores between learners' pre-test and post-tests, as depicted in table 1.

Table 1. The mean scores between learners' pre-test and post-tests

\begin{tabular}{llllll}
\hline & & Mean & N & Std. & Std. Error \\
\cline { 3 - 6 } & & & & Deviation & Mean \\
\hline \multirow{2}{*}{ Pair 1 } & Pre-test of Control Group & 2.6849 & 30 & .26998 & .04929 \\
& Post-test of Control Group & 2.6097 & 30 & .34622 & .06321 \\
\cline { 2 - 6 } Pair 2 & Pre-test of Experimental Group & 2.6882 & 30 & .27676 & .05053 \\
\hline
\end{tabular}

Paired Samples Statistics of Learners' Pre-tests and Post-tests of Reading Attitudes

As illustrated in table 1, the mean score in pre- and post-tests of control group were $\mathrm{M}=2.68$ and $\mathrm{M}=2.60$ respectively, and the mean scores in pre- and post-test of experimental group were $\mathrm{M}=2.68$ and $\mathrm{M}=2.38$ respectively. Since in the scale of the questionnaire, the strongly agree option considered as 1 , and the strongly disagree option got the score 5 (i.e. strongly agree $=1$, agree $=2$, undecided $=3$, disagree $=4$, strongly disagree $=5$ ), the mean score measured in the post-test was lower than the mean score in pre-test; therefore, the lower mean score in the 
post test showed that the treatment changed learners' attitudes positively. Then, to assess the significance of the difference between groups, the researcher run paired samples t-test. The results are presented in table 2 .

Table 2. Significance of the difference between groups

\begin{tabular}{|c|c|c|c|c|c|c|c|}
\hline & \multicolumn{3}{|c|}{ Paired Differences } & \multirow[b]{2}{*}{$\mathrm{t}$} & \multirow[b]{2}{*}{ df } & \multirow{2}{*}{$\begin{array}{l}\text { Sig. } \\
\text { (2-tailed) }\end{array}$} \\
\hline & & Mean & $\begin{array}{l}\text { Std. } \\
\text { Deviation }\end{array}$ & $\begin{array}{l}\text { Std. Error } \\
\text { Mean }\end{array}$ & & & \\
\hline Pair 1 & $\begin{array}{l}\text { Pre-test of Control Group - } \\
\text { Post-test of Control Group }\end{array}$ & .07527 & .43964 & .08027 & .938 & 29 & .356 \\
\hline Pair 2 & $\begin{array}{l}\text { Pre-test of Experimental Group - } \\
\text { Post-test of Experimental Group }\end{array}$ & .33978 & .25297 & .04619 & 7.357 & 29 & .000 \\
\hline
\end{tabular}

Paired Samples T-Test of Learners' Pre-Tests and Post-Tests of Reading Attitudes

Based on the Table 2, there was not any significant difference between learners' pre- and post-tests of control group $(\mathrm{t}(29)=0.938$, $\mathrm{p}>0.05$ ), while there was a statistically significant difference in mean scores between learners' pre-test and post-test of experimental group $(\mathrm{t}(29)=7.35, \mathrm{p}<0.05)$, suggesting that learners' attitudes towards English reading could change when they are taught through strategy instructions.

Furthermore, in order to know how big the difference between the means of pre- and post-tests of experimental group was, the researcher calculated the effect size or the strength of association which showed the relative magnitude of the difference. The following formula was utilized to calculate the means difference. This formula was used in order to check the effect size of the mean differences.

$$
\begin{gathered}
\text { Eta } \text { squared }=\left(t^{\wedge} 2\right) /\left(t^{\wedge} 2+d f\right) \\
\text { Eta } \text { squared }=\left(7.357^{\wedge} 2\right) /\left(7.357^{\wedge} 2+29\right)
\end{gathered}
$$

Then, by putting the values in the formula, the obtained effect size was (0.65), which means that 65 percent of the variances were effective in this study.

\section{RQ. 2. Results of the Second Research Question}

The second research question delved into unknown vocabulary to indicate that if there is any relationship between learners' encounters with unknown vocabularies in English and their attitudes toward reading in English. Therefore, the researcher calculated the correlation between the learners' attitudes towards unknown vocabularies in reading texts 
and towards reading in English. Tables 3 depicted the results, and descriptions related to the results are presented in following.

Table 3. Pearson Correlation Coefficient between the Learners' Attitudes towards Unknown Vocabularies in Reading Texts and Towards Reading in English

\begin{tabular}{llll}
\hline & & $\begin{array}{l}\text { Attitudes towards } \\
\text { Reading }\end{array}$ & $\begin{array}{l}\text { Unknown } \\
\text { Vocabulary }\end{array}$ \\
\hline Attitudes towards Reading & Pearson Correlation & 1 & $-.590^{* *}$ \\
& Sig. (2-tailed) & & .001 \\
& $\mathrm{~N}$ & 30 & 30 \\
Unknown Vocabulary & Pearson Correlation & $-.590^{* *}$ & 1 \\
& Sig. (2-tailed) & .001 & 30 \\
\hline
\end{tabular}

**. Correlation is significant at the 0.01 level (2-tailed).

As demonstrated in Table 3, there was a negative relationship between the learners' attitudes towards unknown vocabularies in reading texts and towards reading in English. In fact, the correlation coefficient was -.59 and the significant value was less than 0.01. Therefore, it can be concluded that there was a negative relationship between the learners' attitudes towards unknown vocabularies in reading texts and towards reading in English. According to the results obtained, the more learners encounter unknown vocabularies, the lower their attitudes towards reading would be.

\section{RQ. 3. Results of the Third Research Question}

In order to know the learners' viewpoints about the effectiveness of contextual inferencing, 20 learners were chosen randomly from the experimental group for the semi-structured interview after the treatment. The interview included five main questions for each learner to answer to. The questions were about the learners' ideas and feelings about explicit instruction of contextual inferencing strategies, the usefulness of the inferencing strategies and if they use them in the future, whether the strategy training is able to change the participants' reading attitudes, if the strategy training motivates them to read more in English, and to find out how they felt about the unknown vocabularies in English texts after strategy training. The majority of the participants reported positive feelings about the strategy training. Moreover, they believed that the contextual inferencing strategies are effective in reading, and they 
planned to use these strategies in the future when they want to read a text so that they can infer the meaning of new words in the context. Some of the learners thought that they may have a wrong understanding of the text and the vocabularies, but most of them mentioned the usefulness of reading strategies. The learners mentioned that the contextual inferencing strategies made them more confident and gave them a good feeling about themselves when they are able to comprehend the text they are reading. Most of them were motivated to read English texts after learning the reading strategies because they believed using these strategies are fun and enjoyable when they understand the texts, and finally, contextual inferencing strategies has helped the majority of the participants in reading comprehension and changed their attitudes towards unknown vocabulary encounters in a positive way, and they were also able to overcome their stress when they encountered new vocabularies in English texts in comparison to the past. Moreover, five major factors were drawn from in participants' responses to the interview questions such as positive attitudes towards reading, the joy of reading, vocabularies in reading, autonomy, and motivation. These factors concluded from learners' responses are presented along with the participants' percentage in table 4 .

Table 4. Percentages of the Factors in Qualitative Data

\begin{tabular}{ll}
\hline Factors & Percentage \\
\hline Attitude towards reading & 0.37 \\
Joy of reading & 0.21 \\
Vocabulary & 0.18 \\
Autonomy in reading & 0.11 \\
Motivation & 0.13 \\
\hline
\end{tabular}

According to the above table, figure 1 shows the percentages of the factors seen in the participants' points of view.

\section{Conclusion}

This study intended to investigate the effect of contextual inferencing on Iranian EFL undergraduates' attitudes towards reading skill, the relationship between unknown vocabulary encounters and learners' attitudes towards reading tasks, and also learners' viewpoints 
regarding the effectiveness of using contextual inferencing strategies in their reading task.

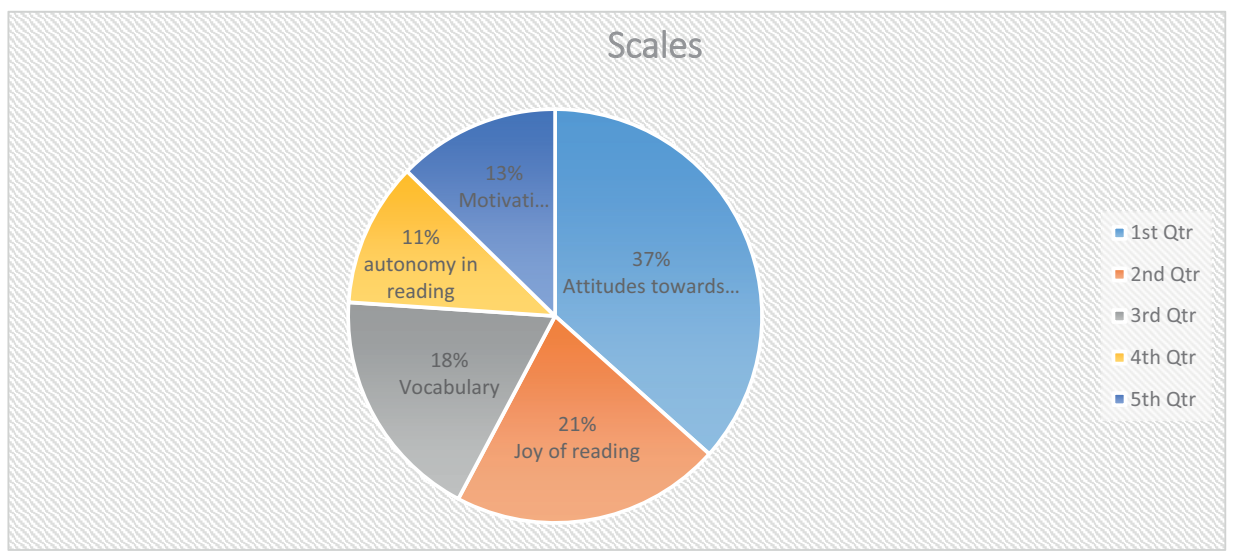

Figure 1. Pie chart showing the percentages of major factors

According to the findings of the study, the participants in experimental group performed better in reading tasks and reading attitude questionnaire as their mean scores in the post-questionnaire were significantly different from their mean scores in pre-questionnaire. This difference in mean scores showed that the instructions in experimental group help learners to change their attitudes towards reading tasks positively. Therefore, it can be concluded that explicit instructions in contextual inferencing strategies affect EFL learners' attitudes towards reading in English.

Moreover, the researcher intended to find out if there is any relationship between Iranian EFL undergraduates' unknown vocabulary encounters and their reading attitude. Based on the results from Pearson Correlation Coefficient performed in this study, there was a negative relationship between learners' encounters with unknown vocabularies and their attitudes towards reading skill. In other words, the more learners come across new words, the lower their attitudes will be towards reading skill. The findings of the study indicated that new vocabularies make reading comprehension difficult for learners, and these difficulties lead to negative attitudes towards reading task.

Finally, the researcher held a revised version of a standard interview in order to find out learners' viewpoints about the usefulness of contextual inferencing strategies in reading task. Most of the 
participants claimed that they found these strategies useful, and they were able to comprehend the text better. According to their responses, using strategies were much better than using dictionary during reading activity, because using dictionary may interrupt the reading process, whereas using contextual inferencing strategies can help them to focus more on the text and infer the meaning of the word by using clues in the context. One or two participants preferred using dictionary because they didn't feel sure about the meaning they guessed from the context by using these strategies. Some other factors were also found in learners' responses due to using contextual inferencing strategies. Leaners felt more independent after learning the strategies, and they did not need their teachers help to complete a reading task. They were also motivated to read more, and they enjoyed reading English text more than they did before as they could comprehend the text better. They were able to guess the meanings of unfamiliar word, and finally they had positive attitudes towards reading skill.

\section{Acknowledgments}

No project of this size and duration can be completed without a great deal of help along the way. Therefore, I must sincerely thank the following people, all of whom have provided me with either technical advice, critical feedback, emotional support, or financial assistance.

Firstly, I wish to express my deepest gratitude to my supervisor, Dr. Amin Marzban, for his endless guidance, support, patience and encouragement in writing this thesis which helped me to sustain the accomplishment of the research. It's an honor for me to thank him for all he has done.

Then, I extend my heartfelt thanks to My Family for providing me with unfailing support and continuous encouragement throughout my years of study and through the process of researching and writing this thesis. This accomplishment would not have been possible without them.

Finally, I gratefully thank the Learners who participated in this study.

\section{References}

Bensoussan, M., \& Laufer, B. (1984). Lexical guessing in context in EFL reading comprehension. Journal of Research in Reading, 7, 15-31. https://doi. org/10.1111/j.1467-9817.1984.tb00252.x 
Carton, S.A. (1971). Inferencing: A process in using and learning language. In P. Pimsleur \& T. Quinn (Eds.), The Psychology of Second Language Learning (pp. 45-58). Cambridge: Cambridge University Press.

Coady, J. (1997a). L2 vocabulary acquisition: A synthesis of the research. In J. Coady \& T. Huckin (Eds.), Second Language Vocabulary Acquisition (pp. 273-290). New York: Cambridge University Press. https://doi.org/10.1017/ CBO9781139524643.020

De Vignemont, F., \& Singer, T. (2006). The empathic brain: How, when and why. Trends in Cognitive Sciences, 10(10), 435-441. https://doi.org/10.1016/j. tics.2006.08.008

Fraser, C.A. (1999). Lexical processing strategy use and vocabulary learning through reading. Studies in Second Language Acquisition, 21, 225-241. https://doi. org/10.1017/S0272263199002041

Fuping, X. (2006). The impact of strategy training on reading comprehension. Journal of CELEA, 29(4), 11-24.

Gardner, R.C., \& MacIntyre, P.D. (1993). A student's contributions to second language learning: Affective variables. Language Teaching, 26, 1-11. https://doi. org/10.1017/S0261444800000045

Grabe, W. (2009). Reading in a second language: Moving from theory to practice. USA: Cambridge University Press. https://doi.org/10.1017/CBO9781139150484

Hulstijn, J. (1992). Retention of Inferred and Given Word Meanings: Experiments in Incidental Vocabulary Learning. In P.J.L. Arnaud \& H. Béjoint (Eds.), Vocabulary and Applied Linguistics (pp. 12-23). Great Britain: MacMillan. https://doi. org/10.1007/978-1-349-12396-4 11

Kaniuka, T.S. (2010). Reading achievement, attitude toward reading, and reading self-esteem of historically low achieving students. Journal of Instructional Psychology, 37(2), 184-188.

Kilian, A.S., Nagy, W.E., Pearson, D.P., Anderson, R.C., \& Garcia, E.G. (1995). Learning Vocabulary From Context: Effects of Focusing Attention on Individual Words During Reading. Urbana Champaign: University of Illinois, Children's Research Center Department.

Kulaç, D. (2011). The effect of explicit instruction in contextual inferencing strategies on students' attitudes towards reading. Doctoral dissertation. Bilkent University. Turkey. https://doi.org/10.1016/j.sbspro.2016.10.066

Kulaç, D., \& Walters, J. (2016). The effect of contextual inferencing strategies on EFL learners' attitudes towards reading. Procedia-Social and Behavioral Sciences, 232, 486-493.

Lazarus, B.D., \& Callahan, T. (2000). Attitudes towards reading experienced by elementary school students diagnosed with learning disabilities. Reading Psychology, 21, 271-282. https://doi.org/10.1080/027027100750061921

Masgoret, A.M., Bernaus, M., \& Gardner, R.C. (2001). Examining the role of attitudes and motivation outside of the formal classroom: A test of the mini-AMTB for children. Motivation and Second Language Acquisition, 53, 281-295.

May, F. (2001). Unraveling the Seven Myths of Reading. Assessment and Intervention Practices for Counteracting Their Effects. Boston: Allyn and Bacon.

Merisuo-Storm, T. (2007). Pupils attitudes towards foreign-language learning and the development of literacy skills in bilingual education. Teaching and Teacher Education, 23, 226-235. https://doi.org/10.1016/j.tate.2006.04.024 
Nassaji, H. (2006). The relationship between depth of vocabulary knowledge and L2 learners' inferencing strategy use and success. The Modern Language Journal, 90(3), 387-401. https://doi.org/10.1111/j.1540-4781.2006.00431.x

Oxford, R. (1990). Language Learning Strategies: What Every Teacher Should Know. Massachusetts: Heinle \& Heinle.

Paribakht, T.S., \& Wesche, M. (1999). Reading and incidental L2 vocabulary acquisition: An introspective study of lexical inferencing. Studies in Second Language Acquisition, 21, 195-224. https://doi.org/10.1017/ S027226319900203X

Schiefele, U., Schaffner, E., Möller, J., \& Wigfield, A. (2012). Dimensions of reading motivation and their relation to reading behavior and competence. Reading Research Quarterly, 47(4), 427-463.

Schmitt, N. (2004). Teaching and learning vocabulary. In J.C. Richards (Ed.), Vocabulary in Language Teaching (pp. 142-162). USA: Cambridge University Press.

Tezdiker, F. (2007). Extensive reading: An analysis of students and teachers perceptions of strengths, weaknesses, and goal attainment. Unpublished master's thesis. Bilkent University, Ankara, Turkey.

Ur, P. (1996). A Course in Language Teaching: Practice and Theory. UK: Cambridge University Press.

Verhoeven, L., \& Perfetti, C. (2008). Advances in text comprehension: Model, process and development. Applied Cognitive Psychology, 22, 293-301. https://doi. org/10.1002/acp.1417

Walters, J. (2004). Teaching the use of context to infer meaning: A longitudinal survey of L1 and L2 vocabulary research. Language Teaching Journal, 37(4), 243-252. https://doi.org/10.1017/S0261444805002491

Walters, J. (2006a). Methods of teaching inferring meaning from context. Regional Language Centre Journal, 37(2), 176-190. https://doi. org/10.1177/0033688206067427

Walters, J. (2006b). Beyond exhortation: Training students of English as a second language to infer meaning from context. Doctoral Dissertation. University of Nottingham, UK.

Wenden, A. (1998). Learner Strategies for Learner Autonomy. Great Britain: Prentice Hall.

Yamashita, J. (2004). Reading attitudes in L1 and L2 and their influence on L2 extensive reading. Reading in a Foreign Language, 16(1), 1-19. https://doi. org/10.1075/itl.135-136.01yam

\section{APPENDIX A}

\section{Students' Attitudes toward Reading in English Questionnaire}

\section{Dear Students,}

The study aims at gathering data about attitudes toward reading in the foreign language. A number of statements about reading in English are presented below. There are no correct or incorrect answers. Your 
ideas are of vital importance because the results will give valuable information for students' attitudes toward reading.

The first part of the questionnaire consists of questions about personal information. The second part includes attitudes toward reading in the foreign language. The third part includes one general question about your attitudes toward reading in English, and the last part includes seven questions about your attitudes toward unknown vocabulary encounters.

All responses will be treated as confidential, and your individual privacy will be maintained in all presented and published data resulting from the study. If you agree to participate in the study, please sign in this form.

\section{Part I:}

Faculty:

Date:

Signature:

Please mark the option that corresponds to your answer.

Sex: ( ) Female ( ) Male

Age: ( ) $16-18$ ( ) $19-21$ ( ) $22-24$ ( ) $25+$

First Semester Level:

Part II: Please mark the option that corresponds to your answer.

\begin{tabular}{|c|c|c|c|c|c|c|}
\hline & & 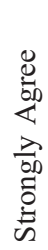 & 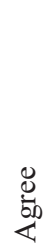 & 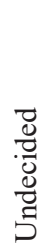 & 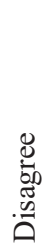 & 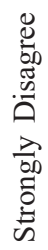 \\
\hline 1 & I only read when I have to. & & & & & \\
\hline 2 & Reading in English is easy for me. & & & & & \\
\hline 3 & $\begin{array}{l}\text { I think I have something more important to do than read in } \\
\text { English. }\end{array}$ & & & & & \\
\hline 4 & I check out books to read in English from the library. & & & & & \\
\hline 5 & I think reading in English is enjoyable. & & & & & \\
\hline 6 & I read in English as much as I can. & & & & & \\
\hline 7 & I think I am a good student in reading in English. & & & & & \\
\hline 8 & Reading in English is an enjoyable pastime for me. & & & & & \\
\hline 9 & $\begin{array}{l}\text { I read magazines and newspapers in English to improve my } \\
\text { English }\end{array}$ & & & & & \\
\hline 10 & I feel confident that I understand what I read. & & & & & \\
\hline
\end{tabular}




\begin{tabular}{|l|l|l|l|l|l|}
\hline 11 & I read on the Internet to improve my English. & & & \\
\hline 12 & I learn a lot when I read in English. & & & \\
\hline 13 & $\begin{array}{l}\text { I have to translate a text into persian in order to understand it } \\
\text { completely }\end{array}$ & & & & \\
\hline 14 & Reading in the class is enjoyable & & & & \\
\hline 15 & In an EFL context, I do not have to be a fluent reader in English. & & & & \\
\hline 16 & Reading in English helps improve my English. & & & & \\
\hline 17 & I like studying reading. & & & & \\
\hline 18 & I need the teacher's help in order to understand the text. & & & \\
\hline 19 & I read aloud what I write in English to improve my English. & & & & \\
\hline 20 & I like reading in English. & & & \\
\hline 21 & I would like to have more hours for the Reading Course. & & & & \\
\hline 22 & I am a good reader in English. & & & & \\
\hline 23 & I try to read something in English when I have free time & & & & \\
\hline 24 & $\begin{array}{l}\text { I read English subtitles of the films when I watch a film to } \\
\text { improve my English }\end{array}$ & & & \\
\hline 25 & I read lyrics of songs in English when I listen to a song. & & & & \\
\hline 26 & Reading in English improves my vocabulary. & & & & \\
\hline 27 & I feel confident when I read in English. & & & & \\
\hline 28 & $\begin{array}{l}\text { I feel comfortable that I understand most of what I read in } \\
\text { English. }\end{array}$ & & & & \\
\hline 29 & $\begin{array}{l}\text { I believe that good readers in English also get higher scores in } \\
\text { the other courses }\end{array}$ & & & & \\
\hline 30 & $\begin{array}{l}\text { Reading in English becomes enjoyable after a short while because } \\
\text { I understand most of what I read. }\end{array}$ & & & & \\
\hline
\end{tabular}

Part III: Please choose one of the options to answer the question. In general, how would you describe your attitude to reading in English? a) I really like to read in English.

b) I like reading in English as long as it isn't too difficult.

c) I don't mind reading in English, but it is difficult for me.

d) I don't like reading in English, but I do it when I have to.

e) I hate reading in English, and I avoid it whenever I can.

Part IV: Please mark the option that corresponds to your answer.

\begin{tabular}{|c|c|c|c|c|c|c|}
\hline & & 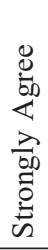 & 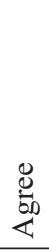 & 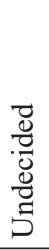 & 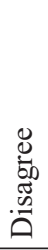 & 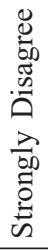 \\
\hline 1. & $\begin{array}{l}\text { The possibility of encountering unknown words in texts does not } \\
\text { affect my feelings about reading in English }\end{array}$ & & & & & \\
\hline
\end{tabular}




\begin{tabular}{|c|l|l|l|l|l|}
\hline 2. & $\begin{array}{l}\text { I feel afraid of encountering unfamiliar words before I start } \\
\text { reading an English text. }\end{array}$ & & & & \\
\hline 3. & $\begin{array}{l}\text { I tend to give up reading when I don't know the meaning of } \\
\text { some words in an English reading text. }\end{array}$ & & & \\
\hline 4. & $\begin{array}{l}\text { I don't like reading something in English when the words are too } \\
\text { difficult. }\end{array}$ & & & \\
\hline 5. & $\begin{array}{l}\text { The unknown words in reading texts keep me away from reading } \\
\text { in English. }\end{array}$ & & & \\
\hline 6. & $\begin{array}{l}\text { I feel anxious when there are a lot of words that I do not know } \\
\text { in an English reading text. }\end{array}$ & & & \\
\hline 7. & $\begin{array}{l}\text { The unknown words are the basic reasons behind my negative } \\
\text { feelings about reading in English. }\end{array}$ & & & \\
\hline
\end{tabular}

\section{APPENDIX B Interview Questions}

1. How did you feel about the inferencing strategy training? What do you think about it?

2. Do you think that contextual inferencing strategies are useful and you will use them in the future?

3. Did the strategy training you received change your attitude towards reading in English?

4. Did the strategy training motivate you to read more in English?

5. How did you feel about the unknown words in English reading texts after the strategy training?

\section{АНОТАЦІЯ}

Мета дослідження. У цьому дослідженні було розглянуто вплив контекстного умовиведення на ставлення студентів Іранського ЕФЛ до читання англійською мовою.

Методики й процедура дослідження. Для досягнення таких цілей 60 студентівбакалаврів Ісламського університету Азад у м. Шираз за фахом викладання англійської мови та вивчення перекладу з англійської мови у віці 19-23 роки були задіяні в дослідженні. Їх розподілили на дві групи випадковим чином: на контрольну та експериментальну групи. Дані були зібрані за допомогою опитувальника "Ставлення до читання» та переглянутої версії інтерв'ю Демета Кулака (2011) у два етапи: до та після інструктажу.

Результати дослідження. Порівняння отриманих даних до та після анкетування показало, що контекстуальні стратегії умови умовиведення позитивно впливають на ставлення студентів до читання, й існує негативний зв'язок між невідомими словами та ставленням тих, хто навчається 
до читання англійських текстів. Нарешті, аналіз інтерв'ю підтвердив ефрективність стратегії тренінгу в ставленні до читання та показав деякі інші фрактори, які були посилені за допомогою контекстуальних стратегій умовиведення.

Висновки. Отримані результати сприяють розробленню навчальних програм та допомагають викладачам встановити розуміння прочитаного, а також у процесі проведення курсів з підготовки до міжнародних тестів.

Ключові слова: контекстуальне умовиведення, лексичне умовиведення, стратегії навчання, ставлення до читання, стратегії читання.

Садегжи Танназ, Марцбан Амин. Контекстуальные стратеги и изменения во взглядах на чтение: на примере иранских выпускников EFL

\section{АННОТАЦИЯ}

Цель. В настоящем исследовании изучалось влияние контекстного вывода на отношение иранских учащихся к английскому языку.

Методы и методики исследования. Для достижения иели в исследовании приняли участие 60 студентов бакалавриата в Университете Исламского Азада в Ширазе, специализирующихся на преподавании английского языка и изучении английского перевода в возрасте от 19 до 23 лет. Студенты были распределены на две группы - контрольную и экспериментальную группы случайным образом. Данные были собраны с помощью вопросника "Отношение к чтению» и пересмотренной версии интервью Демет Кулак (2011) в два этапа - до и после обучения.

Результаты. Сравнение полученных данных до и после анкетирования показало, что контекстные стратегии вывода положительно влияют на отношение учащихся к чтению, а также существует отрицательная связь между неизвестными словарными встречами и отношением учащихся $к$ чтению текстов на английском языке. Наконец, анализ интервью подтвердил эфрективность обучения стратегии в отношении чтения и выявил некоторые другие факторы, которые были усилены с помощью контекстных стратегий вывода.

Выводы. Полученные результаты помогают разработчикам учебных программ и преподавателям в чтении и международных курсах подготовки к экзаменам.

Ключевые слова: контекстный вывод, лексический вывод, стратегии обучения. 